\title{
The challenge of treating central nervous system infections in the developing world
}

\author{
Ranawaka U $\mathbf{K}^{1}$ \\ Journal of the Ceylon College of Physicians, 2018, 49, 2-15
}

\section{Introduction}

Central nervous system (CNS) infections produce high rates of morbidity and mortality. Case fatality rates are in the range of $17-33 \%$ in bacterial meningitis ${ }^{1-3}$, $13-65 \%$ in tuberculous meningitis (TBM) ${ }^{4,5}$, and $20-30 \%$ in Japanese encephalitis (JE) $)^{6,7}$. Residual neurological sequelae are common among survivors; $30-54 \%$ after bacterial meningitis ${ }^{3,8}, 20-47 \%$ after $\mathrm{TBM}^{4,5}$, and $50-60 \%$ after $\mathrm{JE}^{6,7}$. CNS infections produce greater challenges to physicians in developing countries like Sri Lanka, as they are commoner and produce more deaths and disability in these regions ${ }^{9-13}$. Delays in treatment are associated with excess mortality and residual neurological deficits, whereas early treatment has been shown to improve outcome $2,7,10,14-17$.

Early and appropriate treatment depends on rapid and accurate diagnosis. Predicting the type of CNS infection based on clinical findings alone, however, is difficult and unreliable ${ }^{18}$. Typical symptoms of meningitis were shown to have low sensitivity for diagnosis in a meta-analysis ${ }^{19}$. The classical triad of fever, neck stiffness and altered mental state is seen in only $44-46 \% \%^{1,3,19,20}$. Traditional signs of meningeal irritation are poor predictors of meningitis, with a sensitivity of $30 \%$ for neck stiffness, and only 5\% for Kernig's sign and Brudzinski's sign ${ }^{21}$. Establishing the diagnosis, therefore, depends on laboratory investigations, especially cerebrospinal fluid (CSF) analysis. CSF parameters that can independently predict bacterial meningitis (CSF: blood glucose ratio $<0.23$, protein $>2.2 \mathrm{~g} / \mathrm{L}$, leucocyte count $>2000 / \mathrm{cc}$, and a polymorphonuclear leucocyte count $>1180 / c c$ ) are well recognised ${ }^{22}$. However, such changes reflect more severe infection, and are seen only in a minority of cases. CSF cytology, which is widely used in early decision-making, can be negative in up to $10 \%$ with bacterial meningitis, and importantly, these patients have poorer outcomes ${ }^{20,23}$. Simple microbiological

\footnotetext{
${ }^{1}$ Professor in Neurology, Department of Medicine, Faculty of Medicine, University of Kelaniya, Sri Lanka.
}

staining measures that can guide early treatment have poor diagnostic yields. Gram staining of CSF has good specificity in bacterial meningitis (up to $97 \%$ ), but can be negative in $40-75 \%{ }^{24}$. In TBM, sensitivity of ZiehlNielsen staining for acid-fast bacilli (AFB) is only $5-30 \%{ }^{25}$.

Targeted treatment therefore requires isolation of the organisms in blood or CSF, but this is often hindered in developing countries by inadequate diagnostic facilities ${ }^{10,26}$. Blood cultures are positive in about twothirds of patients with bacterial meningitis in developed countries ${ }^{10,20}$, but rates fall to less than one-third in the developing world ${ }^{10,27,28}$. CSF isolation rates are high $(60-73 \%)$ in developed countries ${ }^{1,20,22}$, but much lower (3-35\%) in developing countries ${ }^{10,29-32}$. Tests such as polymerase chain reaction (PCR) based assays for nucleic acid detection facilitate rapid and accurate diagnosis ${ }^{33}$; they are, however, not readily available in developing countries. Several other factors related to resource constraints, such as the lack of treatment facilities, trained personnel and effective treatments adversely affect management of CNS infections in these settings. Clinical decisions on presumptive diagnosis and empiric treatment can only be guided by knowledge of local disease patterns, but such epidemiological data are often lacking from developing countries.

In Sri Lanka, data on the aetiology of CNS infections is limited. Previous published work has been largely confined to individual case reports or case series of specific syndromes ${ }^{29,30,34-37}$.

\section{Methodology}

This oration is based on data from two prospective observational studies designed to describe the clinical spectrum, accuracy of diagnosis, management and early outcome of CNS infection at a Sri Lankan tertiary care hospital (Colombo North Teaching Hospital, Ragama - CNTH). These are the first prospective studies involving unselected adult patients with presumed CNS infection in Sri Lanka. 
Study 1 enrolled all adult patients with suspected CNS infection attending all the medical wards of the CNTH. It was conducted over a two-year period (July 2007 to June 2009), and studied 215 adult patients ${ }^{38}$. Study 2 enrolled all adult and paediatric patients with suspected CNS infection attending all the medical and paediatric wards of the CNTH, and was conducted over a similar duration (July 2009 to June 2011), and studied 374 patients (212 adults, 162 children) $)^{39,40}$. In an extension to Study 2, we aimed to improve the diagnostic yield by collaborating with an overseas institution for analysis of CSF samples in a reference laboratory (Oita University, Japan). The two studies employed similar inclusion criteria, and diagnostic criteria to classify CNS infection. Criteria for enrolment were as follows: any combination of the triad of fever, headache, and vomiting, with any of the following: altered level of consciousness, new-onset seizures, focal neurologic deficits, altered behavior, and signs of meningeal irritation $^{38}$.

\section{Data collection}

We collected data regarding demographic and clinical characteristics, laboratory findings, aetiologies detected, treatment given and early outcome. Patients had standard clinical evaluation, diagnostic work up including neuroimaging and CSF analysis, and treatment available at the CNTH. Management decisions were made by the attending consultants. No additional investigational procedures were performed or treatments given for the purpose of the study. Data was collected by trained pre-intern medical officers who visited the wards every day of the year (including holidays) to ensure completeness of data. All patients were seen within 24 hours of admission and reviewed daily until discharge/death. Information was obtained by interview of patients and relatives, and supplemented by case record review. The data collection instruments were pre-tested in a pilot study over a 3-month period (April-June 2007). Data was entered into a computerised database and analysed using standard statistical software.

\section{Investigation for aetiology}

Blood investigations included total and differential leucocyte counts, erythrocyte sedimentation rate (ESR), C-reactive protein (CRP) levels and bacterial culture. CSF was subjected to protein and glucose measurement, total and differential leucocyte counts, Gram staining, staining for acid-fast bacilli (AFB) and bacterial culture.
CSF samples from patients admitted during the period July 2009-November 2010 were sent to the Oita University, Japan for detailed analysis (Study 2Extension). Bacteria were tested by PCR amplification of $16 \mathrm{~S}$ rRNA, followed by sequencing. The following viruses were tested for by PCR: herpes simplex virus (HSV)-1, HSV-2, varicella-zoster virus (HSV-3), Epsetin-Barr virus (human herpesvirus [HHV] type 4), cytomegalovirus (HHV-5), HHV-6, HHV-7, HHV-8, dengue virus, Japanese encephalitis virus, rubella virus, West Nile virus, yellow fever virus, tick-borne encephalitis virus, Nipah virus, measles virus, mumps virus, parainfluenza virus, respiratory syncytial virus, metapneumovirus, Chikungunya virus, Sindbis virus, Semliki Forest virus, eastern equine encephalitis virus, western equine encephalitis virus, poliovirus, Coxsackie virus, echovirus, enterovirus, lyssaviruses, Chandipura virus, bocavirus (HBoV), rotavirus, astrovirus, norovirus, parechovirus, and human adenovirus (HAdV). On-cell Western analysis (a cellbased assay) was done for anti-N-methyl-D-aspartate receptor (NMDAR) antibodies. CSF samples negative for an aetiological agent were further analysed by deep sequencing for viral genome detection ${ }^{39,40}$.

\section{Case definitions and diagnostic classification}

The initial presumptive diagnosis and the final diagnosis entered at the time of discharge were recorded. The clinical syndrome of CNS infection was classified as meningitis (bacterial, tuberculous or viral), encephalitis, 'meningo-encephalitis', cerebral malaria and cerebral abscess. Data was reviewed after discharge (or death) to assess the accuracy of diagnosis, and the proportion of patients in whom a definitive aetiological diagnosis was established. The final diagnosis of CNS infection was categorized as 'definite', 'probable', 'possible' and 'uncertain', based on the strength of association between clinical features and investigation findings (blood and CSF analysis, neuroimaging, EEG). Patients in whom a diagnosis other than CNS infection was established were labeled as 'alternate diagnosis'38. (Table 1) These categories were based on previously used criteria ${ }^{27,41,42,43,44}$.

\section{Ethical considerations}

Ethical approval for both studies was granted by the Ethics Review Committee of the Faculty of Medicine, University of Kelaniya. The extension to Study 2 was also approved by the Ethics Committee of the Oita University, Japan. Informed written consent was obtained from all participants, or from a relative/ guardian when the participant was unable to provide consent. Administrative approval was obtained from the Director, CNTH. 


\section{Results}

\section{Demographic and clinical characteristics}

The two studies provide data on 589 consecutive patients with CNS infections (427 adults, 162 children) admitted to a single centre over a 4-year period. The main findings are summarised in Tables 2-6. The mean age was 43.1 years $( \pm 19.7)$ in adults, and 3.1 years $( \pm 3.1)$ in children. Males predominated among adults (57.8\%), but not in children (42.6\%) $(p=0.001)$ (Table 2). The classical clinical features such as fever, headache, vomiting and altered consciousness were commonly seen. Headache, altered consciousness, focal signs and meningism were commoner among adults $(p<0.001)$, whereas seizures and behavioural changes were commoner among children $(p<0.001)$. Prior antibiotic use was common $(25.3 \%)$ (Table 2).

Table 1. Case definitions and diagnostic classification of CNS infection $27,41,42,43,44$

\section{On case note review after discharge/ death, the diagnosis in each case was classified as:}

Diagnosis Uncertain

Alternative diagnosis

Possible diagnosis

Probable diagnosis

Definite diagnosis
- compatible clinical picture with or without supporting blood results

- CSF cytology not available

- EEG findings or imaging findings not available

- no confirmation of aetiology (CSF Gram stain, blood or CSF culture, CSF antigen test, blood or CSF serology or PCR)

CNS infection excluded -

- compatible clinical picture with or without supporting blood result

- but, negative CSF findings and negative EEG/ imaging findings OR alternative diagnosis found

- compatible clinical picture

- with or without supporting blood results

- CSF cytology normal

- no supportive evidence on EEG or imaging

- no confirmation of aetiology (CSF Gram stain, blood or CSF culture, CSF antigen test, blood or CSF serology or PCR)

- no alternative diagnosis found

- compatible clinical picture

- supporting CSF cytology or EEG or imaging findings

- no confirmation of aetiology (CSF Gram stain, blood or CSF culture, CSF antigen test, blood or CSF serology or PCR)

- no alternative diagnosis found

- clinical evidence AND

- positive organism detection (CSF Gram stain, blood or CSF culture, CSF antigen test, blood or CSF serology or PCR result)

- no alternative diagnosis found 
(Table 1 continued)

\section{Infection syndromes were classified as:}

Meningitis (bacterial, tuberculous or viral)

Encephalitis

Meningo-encephalitis

Cerebral abscess

Cerebral malaria fever, headache, vomiting, meningeal signs

fever, headache, vomiting, altered level of consciousness, seizures, focal neurological deficits, altered behavior, no meningeal signs

mixed picture - both meningitic and encephalitic features

- Meningo-encephalitis PLUS focal neurological deficits

- abscess noted on CT/MRI

blood film positive for $P$. falciparum

\section{Classification of investigation results}

Blood results were classified as:

Suggestive of bacterial infection raised white cell count (WCC) $>11,000 / \mathrm{mm}^{3}$, and elevated neutrophils $>60 \%$, elevated ESR or CRP

Suggestive of viral infection low or normal WCC and elevated lymphocytes $>50 \%$

\section{CSF results were classified as:}

Suggestive of bacterial infection

Suggestive of viral infection

Suggestive of tuberculous infection / partially treated bacterial infection

Normal turbid or cloudy, elevated proteins, low glucose (low CSF: blood glucose ratio $<50 \%$ ), elevated $W B C>100 / \mathrm{mm}^{3}$, elevated neutrophils $>60 \%$

clear, normal glucose, normal or eleveated protein $(>45 \mathrm{mg} / \mathrm{dl})$, elevated WBC $>5 / \mathrm{mm} 3$, high mononuclear cell/lymphocyte count- $>50 \%$

turbid, elevated protein, low glucose, elevated WBC, high mononuclear cell/lymphocyte count- $>50 \%$

clear, proteins normal ( $<45 \mathrm{mg} / \mathrm{dl}$ ), sugar normal (CSF:blood glucose ratio $>50 \%$ ), cells $<5 / \mathrm{mm}^{3}$ and all lymphocytes

\section{Investigation findings}

Peripheral blood white blood cell (WBC) counts were done in over $95 \%$ of patients, and were elevated in the majority. In contrast, CRP was tested in less than $50 \%$ of patients due to lack of availability at CNTH at the time of the studies; it was elevated in over $50 \%$ of those tested. Blood cultures were done in $33.7 \%$ of adults and $51.9 \%$ of children. In Study 1, a positive blood culture was seen in one patient (S. pneumoniae). In Study 2, blood cultures were positive in five children (S. pneumoniae=1, $H$. influenzae=1, Staph. aureus=3) and three adults (S. pneumoniae=2, Staph. aureus=1).
CT scanning was done in $74 \%$ of adults, with features suggestive of cerebral oedema in 22.2\%; EEG was done in $36.8 \%$ adults, and showed changes suggestive of CNS infection in 28\%; the respective numbers were much smaller for children (Table 3).

CSF analysis was done in all children, and in $80.2 \%$ of adults (overall $81.2 \%$ ). Findings even remotely suggestive of bacterial infection were seen in only a few patients (low glucose - 13\%, presence of at least one neutrophil - 31.1\%). CSF changes more likely to indicate bacterial meningitis (cells $>100 \mathrm{WBC} / \mathrm{mm}^{3}$; 
neutrophils $>80 \%$ of WBC; ratio of CSF:blood glucose $<0.4$; protein $>50 \mathrm{mg} / \mathrm{dl})^{20,45,46}$ were seen in only four patients. CSF Gram stains, AFB stains and cultures were all negative (Table 3). PCR testing in CSF was done in only a few patients due to lack of availability in the state sector and cost constraints; one was positive for $H$. influenzae, and all other samples tested were negative for bacteria and TB.

With the facilities available at the CNTH, a microbiologically proven 'definitive' diagnosis of CNS infection was established in only $12(2 \%)$ patients (Study 1- one patient, 0.5\%; Study 2- eleven patients, 2.9\%). According to the diagnostic criteria, a diagnosis of CNS infection was considered 'probable' in 52.6\% of patients, and 'possible' in $9 \%$. The syndromic diagnosis (in 'definite', 'probable' and 'possible' categories) was meningitis in $32.4 \%$ of patients, encephalitis in $12.9 \%$, and meningo-encephalitis in $19.2 \%$. Five patients had a cerebral abscess diagnosed on neuroimaging. Diagnosis of CNS infection was considered 'uncertain' in $13.2 \%$, and an 'alternative diagnosis' was found in $21.4 \%$ (Tables 4,6 ).

\section{Treatment and Outcome}

Over $90 \%$ of the patients were given intravenous antimicrobial therapy on empiric grounds, mostly without microbiological confirmation; 3rd generation cephalosporins in $78.6 \%$ of patients, and acyclovir in $56.2 \%$. Intravenous steroids were used in $31.9 \%$ of patients. Mean duration of hospital stay (SD) was 8.9 (5.7) days. Most patients (81\%) were discharged home, and 31 patients (5.3\%, all adults) died during hospital stay (Table 5).

Table 2. Demographic and clinical characteristics

\begin{tabular}{|c|c|c|c|c|c|c|c|c|c|c|c|}
\hline & \multicolumn{2}{|c|}{$\begin{array}{l}\text { Study } 1 \\
(n=215)\end{array}$} & \multicolumn{2}{|c|}{$\begin{array}{l}\text { Adults } \\
\text { Study } 2 \\
(n=212)\end{array}$} & \multicolumn{2}{|c|}{$\begin{array}{c}\text { Total } \\
(n=427)\end{array}$} & \multicolumn{2}{|c|}{$\begin{array}{l}\text { Children } \\
\text { Study } 2 \\
(n=162)\end{array}$} & \multicolumn{2}{|c|}{$\begin{array}{c}\text { Total } \\
(n=589)\end{array}$} & \\
\hline & No & $\%$ & No & $\%$ & No & $\%$ & No & $\%$ & No & $\%$ & \\
\hline \multicolumn{12}{|c|}{ Demographic data } \\
\hline Sex-Male & 127 & 59.1 & 120 & 56.6 & 247 & 57.8 & 69 & 42.6 & 316 & 53.7 & $P=0.001$ \\
\hline Mean age (SD) & \multicolumn{2}{|c|}{$44(20)$} & \multicolumn{2}{|c|}{$44.7(19.6)$} & \multicolumn{2}{|c|}{$43.1(19.7)$} & \multicolumn{2}{|c|}{$3.1(3.1)$} & \multicolumn{2}{|c|}{$36.3(23.1)$} & \\
\hline Prior antibiotic use & 33 & 15.3 & 71 & 33.5 & 104 & 24.4 & 45 & 27.8 & 149 & 25.3 & $P=0.455$ \\
\hline
\end{tabular}

\section{Clinical features}

$\begin{array}{lccccccccccc}\text { Fever } & 179 & 83.3 & 167 & 78.8 & 346 & 81 & 151 & 93.2 & 497 & 84.4 & \mathbf{P}<0.001 \\ \begin{array}{l}\text { Altered } \\ \text { consciousness }\end{array} & 149 & 69.3 & 98 & 46.2 & 247 & 40.7 & 35 & 21.6 & 282 & 47.9 & \mathbf{P}<0.001 \\ \text { Headache } & 153 & 71.2 & 118 & 55.7 & 271 & 63.5 & 57 & 35.2 & 328 & 55.7 & \mathbf{P}<0.001 \\ \text { Vomiting } & 116 & 54.0 & 58 & 27.4 & 174 & 40.7 & 84 & 51.9 & 258 & 43.8 & \mathbf{P}=\mathbf{0 . 0 1 5} \\ \text { Photophobia } & 53 & 24.7 & 39 & 18.4 & 92 & 21.5 & 10 & 6.2 & 102 & 17.3 & \mathbf{P}<\mathbf{0 . 0 0 1} \\ \text { Behavioral changes } & 101 & 47 & 53 & 25 & 154 & 36.1 & 87 & 53.7 & 241 & 40.9 & \mathbf{P}=\mathbf{0 . 0 2 5} \\ \text { Focal signs } & 33 & 15.3 & 16 & 7.5 & 49 & 11.5 & 4 & 2.5 & 53 & 9 & \mathbf{P}=-\mathbf{0 . 0 0 1} \\ \text { Seizures } & 59 & 27.4 & 16 & 7.5 & 75 & 17.6 & 66 & 40.7 & 141 & 23.9 & \mathbf{P}<\mathbf{0 . 0 0 1} \\ \text { Meningism } & 92 & 42.8 & 90 & 42.5 & 182 & 42.6 & 43 & 26.5 & 225 & 38.2 & \mathbf{P}<0.001 \\ & & & & & & & & & & \end{array}$


Table 3. Investigations

\begin{tabular}{|c|c|c|c|c|c|c|c|c|c|c|}
\hline & \multicolumn{2}{|c|}{$\begin{array}{c}\text { Study } 1 \\
(n=215) \\
\text { (no./no. } \\
\text { performed) }\end{array}$} & \multicolumn{2}{|c|}{$\begin{array}{c}\text { Adults } \\
\text { Study } 2 \\
\text { (n=212) } \\
\text { (no./no } \\
\text { performed) }\end{array}$} & \multicolumn{2}{|c|}{$\begin{array}{c}\text { Total } \\
(n=427) \\
\text { (no./no } \\
\text { performed) }\end{array}$} & \multicolumn{2}{|c|}{$\begin{array}{c}\text { Children } \\
\text { Study } 2 \\
(n=162) \\
\text { (no./no } \\
\text { performed) }\end{array}$} & \multicolumn{2}{|c|}{$\begin{array}{c}\text { Total } \\
\text { (n=589) } \\
\text { (no./no } \\
\text { performed) }\end{array}$} \\
\hline & No & $\%$ & No & $\%$ & No & $\%$ & No & $\%$ & No & $\%$ \\
\hline \multicolumn{11}{|l|}{ Blood investigations } \\
\hline$E S R>20$ & $44 / 140$ & 31.4 & $96 / 122$ & 78.7 & $140 / 262$ & 53.4 & $7 / 8$ & 87.5 & $147 / 270$ & 54.4 \\
\hline $\mathrm{CRP}>12$ & $38 / 54$ & 70.4 & $54 / 105$ & 51.4 & $92 / 159$ & 57.9 & $64 / 127$ & 50.4 & $156 / 286$ & 54.6 \\
\hline WBC $>11000$ & $124 / 201$ & 61.7 & $100 / 200$ & 50 & $224 / 401$ & 55.9 & $105 / 160$ & 65.6 & $329 / 570$ & 57.7 \\
\hline Blood Culture positive & $1 / 65$ & 1.5 & $3 / 79$ & 3.8 & $4 / 144$ & 2.1 & $5 / 84$ & 5.9 & $9 / 228$ & 3.9 \\
\hline
\end{tabular}

\section{CSF analysis}

$\begin{array}{lccccccccccc}\text { CSF done } & 146 & 67.9 & 170 & 80.2 & 316 & 74 & 162 & 100 & 478 & 81.2 \\ \text { Protein >45 } & 100 / 146 & 68.4 & 105 / 170 & 61.8 & 205 / 316 & 64.9 & 98 / 162 & 60.5 & 303 / 478 & 63.4 \\ \text { Sugar<1/2 RBS } & 28 / 146 & 19.2 & 25 / 170 & 14.7 & 53 / 316 & 16.8 & 24 / 162 & 14.8 & 77 / 478 & 16.1 \\ \text { PMN>1 } & 64 / 146 & 43.8 & 47 / 170 & 27.7 & 111 / 316 & 35.1 & 72 / 162 & 44.4 & 183 / 478 & 38.3 \\ \text { Lymphocytes>5 } & 72 / 146 & 49.3 & 73 / 170 & 42.9 & 145 / 316 & 45.9 & 90 / 162 & 55.5 & 235 / 478 & 49.2 \\ \text { CSF Gram stain positive } & 0 / 78 & 0 & 0 / 113 & 0 & 0 / 113 & 0 & 0 / 152 & 0 & 0 / 343 & 0 \\ \text { CSF culture positive } & 0 / 70 & 0 & 0 / 113 & 0 & 0 / 186 & 0 & 0 / 151 & 0 & 0 / 337 & 0 \\ \text { AFB in CSF positive } & 0 / 42 & 0 & 0 / 89 & 0 & 0 / 131 & 0 & 0 / 1 & 0 & 0 / 132 & 0\end{array}$

\section{Other investigations}

CT scan -

$\begin{array}{lllllllllll}\text { Cerebral oedema } & 35 / 151 & 23.2 & 35 / 165 & 21.2 & 70 / 316 & 22.2 & 5 / 7 & 71.4 & 70 / 323 & 21.7 \\ \text { EEG Abnormal } & 19 / 83 & 22.9 & 25 / 74 & 33.7 & 44 / 157 & 28 & 3 / 18 & 16.7 & 47 / 323 & 14.6\end{array}$

(Units of measurement: ESR - mm/1st $\mathrm{h}$; CRP - mg/L; WBC - cells $/ \mathrm{mm}^{3} ;$ CSF protein - $\mathrm{mg} / \mathrm{dL} ;$ CSF cell counts - cells/ $\mathrm{mm}^{3}$ ) 
Table 4. Diagnosis reached after investigation at CNTH

\begin{tabular}{|c|c|c|c|c|c|c|c|c|c|c|}
\hline & \multicolumn{2}{|c|}{$\begin{array}{l}\text { Study } 1 \\
(n=215)\end{array}$} & \multicolumn{2}{|c|}{$\begin{array}{l}\text { Adults } \\
\text { Study } 2 \\
(n=212)\end{array}$} & \multicolumn{2}{|c|}{$\begin{array}{c}\text { Total } \\
(n=427)\end{array}$} & \multicolumn{2}{|c|}{$\begin{array}{l}\text { Children } \\
\text { Study } 2 \\
(n=162)\end{array}$} & \multicolumn{2}{|c|}{$\begin{array}{c}\text { Total } \\
(n=589)\end{array}$} \\
\hline & No & $\%$ & No & $\%$ & No & $\%$ & No & $\%$ & No & $\%$ \\
\hline \multicolumn{11}{|l|}{ Clinical syndrome } \\
\hline Meningitis & 36 & 16.7 & 78 & 36.8 & 114 & 26.7 & 77 & 47.5 & 191 & 32.4 \\
\hline Encephalitis & 33 & 15.3 & 39 & 18.4 & 72 & 16.9 & 4 & 2.5 & 76 & 12.9 \\
\hline Meningo-encephalitis & 63 & 29.3 & 49 & 23.1 & 112 & 26.2 & 1 & 0.6 & 113 & 19.2 \\
\hline Cerebral abscess & 4 & 1.9 & 1 & 0.5 & 5 & 1.1 & 0 & 0.0 & 5 & 0.8 \\
\hline Uncertain diagnosis & 56 & 26 & 18 & 8.5 & 74 & 17.3 & 4 & 2.5 & 78 & 13.2 \\
\hline Alternative diagnosis & 23 & 10.7 & 27 & 12.7 & 50 & 11.7 & 76 & 46.9 & 126 & 21.4 \\
\hline \multicolumn{11}{|c|}{ Categorization according to diagnostic certainty } \\
\hline Definitive diagnosis & 1 & 0.5 & 4 & 1.9 & 5 & 1.2 & 7 & 4.3 & 12 & 2.0 \\
\hline Probable diagnosis & 123 & 57.2 & 136 & 64.7 & 249 & 58.5 & 61 & 37.7 & 310 & 52.6 \\
\hline Possible diagnosis & 12 & 5.6 & 27 & 12.7 & 39 & 9.1 & 14 & 8.6 & 53 & 9.0 \\
\hline Uncertain diagnosis & 56 & 26 & 18 & 8.5 & 74 & 17.3 & 4 & 2.5 & 78 & 13.2 \\
\hline Alternative diagnosis & 23 & 10.7 & 27 & 12.7 & 50 & 11.7 & 76 & 46.9 & 126 & 21.4 \\
\hline
\end{tabular}

\section{Results of the Study 2 Extension - CSF analysis at Oita University, Japan}

233 patients in Study 2 (110 adults, 123 children) enrolled during the period July 2009-November 2010 were considered for detailed CSF analysis. CSF samples from 191 patients were sent to the Oita University, Japan. Analysis of these samples confirmed the presence of the following organisms: Dengue virus (1 patient; DEN-2), Echovirus (2 patients; HEcoV 9, HEcoV 25), Adenovirus (7 patients; all HAdV 41). Two patients (out of 81 tested) had immune-mediated encephalitis with anti-NMDAR antibodies ${ }^{39}$ (Table 6).

In addition to these, two exciting findings were made. Firstly, Human Bocavirus was identified in five patients by PCR (HBoV-1,2,3). Phylogenetic analysis showed that these genomes shared some similarities with, but were not identical to, those described in Bangladeshi children ${ }^{39}$. On further analysis of negative CSF samples by deep sequencing, genomes of two new small circular single-stranded DNA (ssDNA) viruses were identified, a Cyclovirus (one patient) and Gemycircularvirus (three patients). They belong to a group of viruses with circular, replication initiator protein encoding, single stranded DNA (CRESS-DNA) genomes. Phylogenetic analysis revealed that these genomes were distinct from those previously described, and were designated CyCV-SL and GemyCV-SL ${ }^{40}$. The association of bocavirus (HBoV), cycloviruses and gemycircularviruses with meningoencephalitis had been described only recently $47,48,49$. 
Table 5. Treatment given and Outcome

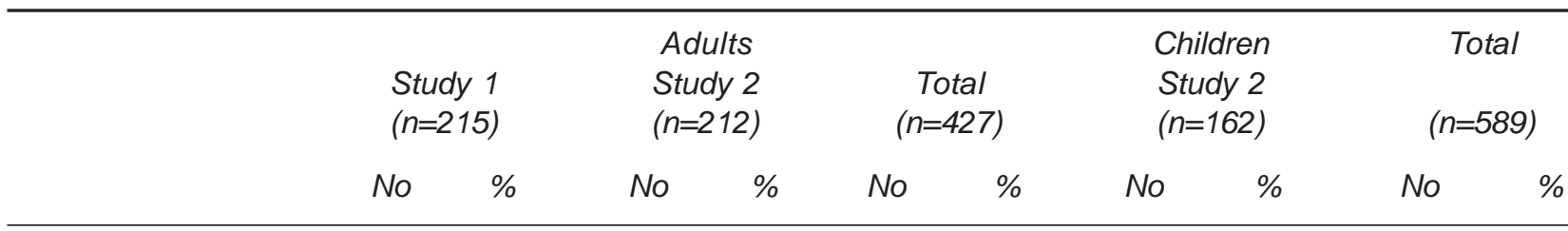

Treatment given (intravenous drugs)

$\begin{array}{lcccccccccc}\text { Penicillin } & 52 & 24.2 & 23 & 10.8 & 75 & 17.6 & 22 & 13.5 & 97 & 16.5 \\ \begin{array}{l}3^{\text {rd }} \text { generation } \\ \text { cephalosporin }\end{array} & 181 & 84.2 & 170 & 80.2 & 351 & 82.2 & 112 & 69.1 & 463 & 78.6 \\ \begin{array}{l}\text { Acyclovir } \\ \text { Dexamethasone }\end{array} & 133 & 61.9 & 123 & 58.0 & 256 & 59.9 & 75 & 46.2 & 331 & 56.2 \\ \text { Mannitol } & 82 & 38.1 & 62 & 29.2 & 144 & 33.8 & 44 & 27.2 & 188 & 31.9 \\ & 66 & 30.7 & 38 & 17.9 & 104 & 24.3 & 27 & 16.6 & 131 & 22.2 \\ & & & & & & & & & & \end{array}$

Duration of hospital stay (days)

$\begin{array}{llllll}\text { Mean }(\mathrm{SD}) & 9.2(6.8) & 9.7(5.2) & 9.5(6.1) & 7.1(3.8) & 8.9(5.7)\end{array}$

\section{Outcome}

\begin{tabular}{|c|c|c|c|c|c|c|c|c|c|c|}
\hline Discharged home & 153 & 71.2 & 164 & 77.4 & 317 & 74.2 & 160 & 98.8 & 477 & 81 \\
\hline Death & 20 & 9.3 & 11 & 5.2 & 31 & 7.26 & 0 & 0.0 & 31 & 5.3 \\
\hline $\begin{array}{l}\text { Transferred for } \\
\text { further care }\end{array}$ & 32 & 14.9 & 31 & 14.6 & 63 & 14.8 & 1 & 0.6 & 64 & 10.9 \\
\hline $\begin{array}{l}\text { Left hospital - } \\
\text { destination unknown }\end{array}$ & 10 & 4.7 & 6 & 2.8 & 16 & 3.74 & 1 & 0.6 & 17 & 2.9 \\
\hline
\end{tabular}

CSF analysis in Japan thus increased the diagnostic yield to 32 out of 374 patients (8.6\%) in Study 2. (Table 6) After excluding those with 'uncertain' and 'alternative' diagnoses, the yield was $12.9 \%$ among those more likely to have a CNS infection ('definite', 'probable' and 'possible'). However, almost 90\% of patients remained without an aetiological diagnosis even after extensive investigation.

\section{Discussion}

\section{Key findings and interpretation}

This oration summarises the findings of two prospective studies on CNS infections in Sri Lanka. They were conducted in the same setting, over a similar duration, with identical inclusion/ exclusion criteria and similar methodology. They were the first- ever prospective studies on adult patients in the country, and provide data from the largest case series to date of adult and paediatric Sri Lankan patients.

The key finding from the studies is the difficulty in establishing a microbiological diagnosis, and the resultant low diagnostic yield. In Study 1, a definitive aetiological diagnosis was made in only one out of 215 patients. In Study 2, only 11 out of 374 patients $(2.9 \%)$ had a definitive diagnosis with the facilities available at the CNTH. On further analysis of CSF at an overseas laboratory, a cause was identified in 21 additional patients, increasing the yield to 32 (8.6\%). In about two-thirds (62\%) of patients where a diagnosis of CNS infection seemed highly likely ('probable' and 'possible' categories), we could not establish a microbiological causation (Table 4). 
Table 6. Aetiological diagnoses identified

\begin{tabular}{ccc}
\hline Study 1 & $\begin{array}{c}\text { Study } 2 \\
\text { (CNTH analysis) }\end{array}$ & $\begin{array}{c}\text { Study 2 Extension } \\
\text { (Analysis in Japan) }\end{array}$ \\
Adults & Adults + Children & Adults + Children \\
$(n=215)$ & $(n=374)$ & $(n=191)$
\end{tabular}

\section{Blood culture}

$\begin{array}{ll}\text { S. pneumoniae }(\mathrm{n}=1) & \text { S. pneumoniae }(\mathrm{n}=3) \\ & \text { Staph. aureus }(\mathrm{n}=4) \\ \text { H. influenzae }(\mathrm{n}=1)\end{array}$

\section{Serology}

Japanese Encephalitis $(n=1) \quad$ Enterovirus $(n=1)$

\section{CSFPCR}

\section{$H$. influenzae $(n=1)$}

\author{
Dengue virus - DEN-2 $(n=1)$ \\ Echovirus - HEcoV 9, HEcoV $25(n=2)$ \\ Adenovirus - HAdV $41(n=7)$ \\ Human Bocavirus - HBoV-1,2,3 ( $n=5)$
}

\section{Genome detection}

Cyclovirus - CyCV-SL ( $\mathrm{n}=1)$

Gemycircularvirus - GemyCV-SL $(n=3)$

\section{On-cell Western analysis}

Anti-NMDAR antibody $(\mathrm{n}=2)$

\section{Total aetiologies identified}

$\mathrm{n}=1,0.46 \%$

$\mathrm{n}=11,2.94 \%$

$\mathrm{n}=21,10.9 \%$
Lack of modern diagnostic facilities in the state sector is likely to be the main reason for the very low rate of isolation of organisms. However, suboptimal management practices are possible contributory factors, such as the failure to carry out even the routinely available investigations (e.g, blood cultures were done in only 39\%). Delays in performing lumbar puncture and blood cultures, and improper techniques in specimen handling, can lead to negative results. We tried to minimise the influence of these during Study 2 with several measures such as staff briefings. An audit is currently underway to evaluate the management practices in detail with a view to identifying deficiencies and introducing remedial measures. Prior antibiotic use is likely to be an important factor for a poor diagnostic yield, and is common (27-61\%) in developing countries $27,31,32$, compared to about $15 \%$ reported from developed countries ${ }^{3}$. In our study, 25\% of the patients had been treated with antibiotics prior to hospital admission (Table 2).

We were unable to detect any cases of cerebral malaria or TBM. Malaria was almost eradicated in Sri Lanka at the time of the studies. Tuberculosis remains a major health problem in the country, and the failure to detect TBM is likely due to a combination of factors such as inadequate testing (AFB staining, culture) and lack of newer techniques such as TB-PCR. However, our findings also raise concerns regarding the widespread practice of empiric use of anti-TB chemotherapy in suspected CNS infection, based solely on a lymphocytic-predominant CSF without diagnostic confirmation. 
Our findings warrant a critical analysis of the available literature. The low isolation rates in our studies are is similar to reports from many developing countries, and are usually attributed to the lack of diagnostic facilities ${ }^{10,26}$. However, low isolation rates are common in developing countries even when supported by good microbiological facilities, as shown by many studies. In two Vietnamese studies, a microbiological cause was not found in $73 \%$ of adults ${ }^{50}$, and $59 \%$ of children ${ }^{51}$. In the South Asian Pneumococcal Alliance Network (SAPNA) study of children aged $<5$ years with suspected meningitis, bacterial meningitis was confirmed in only $3.1 \%$ of CSF samples in Pakistan ${ }^{32}$, and $8.5 \%$ in Sri Lanka (Batuwantudawe et al, 2009) $^{29}$. In another study of children $<5$ years in Colombo, an organism was isolated in only $9.4 \%$ CSF specimens, and only $2.3 \%$ had a positive culture (Batuwantudawe et al, 2010) ${ }^{30}$. Two Sri Lankan studies, conducted subsequent to our studies, have confirmed the difficulties in diagnosis in spite of access to good microbiological facilities. In a study by Danthanarayana et al (2015), Enterovirus (E-9) was detected in nine out of 39 CSF samples, and the samples were negative for all other viruses tested and bacterial culture ${ }^{52}$. Lohitharahjah et al (2017) identified a viral aetiology in $27.3 \%$ of 99 CSF samples from 108 patients with suspected encephalitis/ meningo-encephalitis; the aetiologies identified included dengue virus, JE virus, varicella zoster virus and West Nile virus. Bacterial causes and HSV were not detected ${ }^{53}$.

A closer analysis of the published literature reveals that reported high isolations rates can perhaps be misleading ${ }^{54}$. Most studies reporting high isolation rates are from case series with a defined syndrome (bacterial meningitis, viral encephalitis, etc.), are retrospective studies, or describe only microbiologically or serologically proven cases ${ }^{1,2,3,20,55,56}$. These would naturally show higher isolation rates. Data from unselected patients with clinically suspected CNS infection, as in our study, is limited ${ }^{41-44,57,58}$. Such data is more important for 'point of care' clinical decision making in the acute stage, as patients do not present with a label of 'bacterial meningitis' or 'viral encephalitis', but with a diagnostically challenging clinical syndrome of febrile meningo-encephalopathy (meningo-encephalitis) ${ }^{54}$. Similar studies with unselected patient recruitment based on a presumptive clinical diagnosis of CNS infection have reported much lower rates of isolation even from developed countries, similar to our findings ${ }^{41-}$ $44,58-60$. In a multicentre study from UK, only $20 \%$ out of 217 suspected patients were found to have a CNS infection, and CSF culture was positive in only 3 out of 199 samples $^{43}$. In a national level survey in UK, 60\% of the cases were of unknown aetiology ${ }^{59}$. An infectious cause was detected in only $37 \%$ of patients in another multi-centre study in UK ${ }^{44}$. In the California Encephalitis Project, a 'confirmed or probable' cause was found in only $16 \%$ of patients, and an aetiological agent was not found in $62 \%$ of patients despite extensive testing ${ }^{42}$. Up to $85 \%$ of cases worldwide are reported to be due to undetected causes ${ }^{44}$.

It is likely that there are many other potential reasons for a low diagnostic yield. The possibility of a broader spectrum of neurotropic organisms, not considered in the traditional list of differential diagnosis and not detected by the usual tests for CNS infection, needs serious consideration. Furthermore, the epidemiological patterns seem to be changing in South Asia, and worldwide. We found several cases of dengue, echo- and adenovirus infections. Dengue is now considered one of the main aetiologies of encephalitis in endemic regions ${ }^{61-64}$. Increasing global travel can introduce previously unseen organisms to new territories, e.g, West Nile virus encephalitis is now reported from the South Asian region, including Sri Lanka ${ }^{65-67}$. Emerging infections such as Nipahvirus encephalitis is increasingly recognised from South East Asia ${ }^{68-71}$. Interestingly, the two subsequent Sri Lankan studies cited earlier detected only viral aetiologies and failed to isolate any bacterial causes ${ }^{52,53}$. Alternate diagnoses such as encephalopathy are common in unselected samples, e.g. $79.7 \%$ of suspected CNS infection in a multi-centre study in UK ${ }^{43} ; 31.3 \%$ of suspected bacterial meningitis in Ethiopia ${ }^{72} ; 10 \%$ of suspected encephalitis in the California Encephalitis Project ${ }^{42}$. In our studies, an 'alternate diagnosis' was found in $21.4 \%$ (adults $12.7 \%$, children $-46.9 \%, \mathrm{p}=0.001$ ). Furthermore, recent reports indicate that non-infectious causes of encephalitis, such as immune-mediated encephalitis, may be at least as common as infectious causes. In patients aged $<30$ years in the California Encephalitis Project, immune-mediated encephalitis due to anti-Nmethyl-D-aspartate receptor (anti-NMDAR) antibodies was commoner than viral aetiologies ${ }^{73}$. Immunemediated encephalitis was found in $21 \%$ of patients with encephalitis in England ${ }^{44}$, and in $24 \%$ in Thailand ${ }^{74}$. We found two patients with anti-NMDAR encephalitis in Study 2.

Over the years, we may well have been overlooking the possible existence of a completely different spectrum of neurotropic organisms, not previously considered as pathogens causing CNS infection. Several hitherto unsuspected novel agents, such as Bocavirus, Cyclovirus and Gemycircularvirus, were isolated in our patients ${ }^{39,40}$. The association of Bocavirus with encephalitis was previously described only in one report from Bangladesh ${ }^{47}$. Cyclovirus has 
only been previously reported in association with CNS involvement from Vietnamese children and Malawi adults ${ }^{48,49}$. To our knowledge, ours was the first report of an association of Gemycircularvirus with CNS infection. The causal importance of these organsims in CNS infection is yet to be determined. However, these findings were considered important enough to be highlighted with special mention in the respective journals ${ }^{75,76}$. Both Bocavirus and Cyclovirus have more recently been reported from patients with encephalitis, increasing their likelihood of being causal pathogens ${ }^{77,78}$.

Many patients in our studies were treated with intravenous antibiotics on clinical suspicion, without confirmation of CNS infection. This practice is widespread in many developing countries where diagnostic facilities are limited; e.g., bacterial meningitis was confirmed in only $3.3 \%$ of patients with suspected meningitis in Ethiopia, but all patients were given intravenous antibiotics ${ }^{57}, 58 \%$ of patients with suspected meningitis in Nigeria were treated empirically without CSF analysis ${ }^{79}$. This is a pragmatic approach to emergent management in view of the high mortality and morbidity associated with CNS infection. However, it also carries the risks of overlooking many potentially treatable diagnoses, and a high cost of unnecessary treatment. Interestingly, no cases of microbiologically confirmed HSV encephalitis were found in our study and in the two subsequent Sri Lankan studies described ${ }^{52,53}$. Intravenous acyclovir is widely used on an empiric basis in patients with suspected meningo-encephalitis in Sri Lanka, as was seen in our studies, and these findings challenge the rationale for this practice.

Practice guidelines for empiric treatment are based on epidemiological data from developed countries; such data are not available for developing countries. Disease patterns in these countries may well be different, as our findings suggest. Furthermore, there is little evidence for using some of the guideline-based treatments in the developing countries. Adjunctive dexamethasone therapy is widely recommended in bacterial meningitis but several studies have failed to show a benefit in developing countries ${ }^{27,28,80}$. A study in Ethiopia found excess mortality with adjunctive dexamethasone therapy, but mortality was not increased in the microbiologically proven cases, highlighting the importance of accurate diagnosis guiding empiric treatment ${ }^{72}$.

\section{Strengths and Limitations}

The main strengths of these studies include the large number of participants, recruitment of consecutive patients with suspected CNS infection admitted to all the medical units (and all the paediatric units in Study 2) of a busy teaching hospital, and prospective data collection over a long period. The similarities in the patient numbers, patient characteristics and findings between adults in the two studies point to the goodness of the data.

Several limitations need to be acknowledged. Between-unit variations in practice may have affected diagnostic work up and treatment; we did not investigate this. We also did not investigate the possible impact of deficiencies in management, such as delays in performing investigations. Our findings are from a single urban centre, and data may well be different from other parts of the country. A selection bias is possible as many patients referred from smaller hospitals to a tertiary care centre are included. This data may not be a true reflection of the pattern of CNS infections in the community, as more severe patients may die before reaching hospital and mild undiagnosed cases may be treated at home. However, most patients with acute CNS infections are likely to seek hospital treatment. Community based studies on CNS infections are virtually impossible due to the need for in-hospital evaluation and management, and almost all the reports in the literature are based on hospital derived data. We believe our data is representative of adults and children with CNS infection attending a large Sri Lankan hospital.

\section{Conclusions and Recommendations}

These studies highlight the difficulties in establishing a diagnosis in patients with suspected CNS infection in Sri Lankan hospitals. Our findings challenge the traditional approach to the management of CNS infections, and point to the need for 'thinking outside the box' - searching beyond the traditional mind set for a broader range of possible organisms. These findings are strengthened by similar data from other studies, from Sri Lanka and many other countries. Failure to establish an accurate diagnosis would naturally lead to inappropriate treatment, and possibly death and disability. It also has huge financial implications which developing countries such as Sri Lanka can ill afford; e.g., treatment of many patients with expensive antimicrobials on empiric grounds and prolonged hospital stays. Availability of rapid and accurate diagnostic facilities in state sector hospitals is likely to minimise treatment costs, in addition to improving patient care. Investigations such as PCR which are standard practice in other countries should be made available to practicing clinicians. 


\section{The challenge for Sri Lankan physicians?}

Getting the treatment right in the critical first few hours depends on getting the diagnosis right. This is particularly challenging in resource-limited settings such as Sri Lanka where CNS infections are more prevalent, due to a multitude of factors such as lack of rapid diagnostic facilities, widesjpread prior antibiotic use and lack of epidemiological data. There is a clear need for national-level research into the aetiology of CNS infections and antibiotic sensitivity patterns. A shift in our approach to CNS infections, and searching beyond the traditional diagnostic paradigms for previously unsuspected infectious agents and noninfectious causes deserves more attention. Use of modern diagnostic tools and newer antibiotics would add to the cost of care, but this would be money well spent, on minimising disability and saving lives.

\section{Acknowledgements}

I sincerely thank the following for their contributions: Collaborators at the Faculty of Medicine, University of Kelaniya (EGDS Rajindrajith, KVHKK Perera, BAHR Premaratne, Wijesooriya T, HJ de Silva); Collaborators at the Colombo North Teaching Hospital, Ragama (KMMP Dassanayake, SMSB Samarakoon, G Premawansa, K Thirumawalawan, A Kulatunga, MAM Fernando, L de Silva, WAJN Tissera, DKMMS Cooray); Overseas Collaborators (Kamruddin Ahmed, Eric Delwart, D Mori, TG Phan, K Yamada, K Miya, T Matsumoto, MT Mitui, H Mori, A Nishizono, M Söderlund-Venermo, X Deng, TF Fan Ng, F BucardoRivera, P Orlandi); Pre-intern medical officers who collected and entered data (ML Harshani, VNRM Fonseka, KLW Hathagoda, ANHMUKGDB Nawaratne, WALK Weerasooriya, NBANA Kumari, WRS Wimalarathne); Pre-intern medical officers who helped with data analysis (RMSP Muwanhella, DDVLS Bandara); All the staff in medical and paediatric units at the Colombo North Teaching Hospital, Ragama; All the Patients.

\section{References}

1. Durand ML, Calderwood SB, Weber DJ, et al. Acute bacterial meningitis in adults: a review of 493 episodes. N Engl J Med. 1993; 328: 21-28.

2. Køster-Rasmussen R, Korshin A, Meyer CN. Antibiotic treatment delay and outcome in acute bacterial meningitis. J Infect. 2008; 57: 449-54.

3. Weisfelt M, van de Beek D, Spanjaard L, et al. Clinical features, complications, and outcome in adults with pneumococcal meningitis: a prospective case series. Lancet Neurol. 2006; 5: 123-9.
4. Hosoglu S, Ayaz C, Geyik MF, et al. Tuberculous meningitis in adults: an eleven-year review. Int J Tuberc Lung Dis. 1998; 2: 553-7.

5. Farinha NJ, Razali KA, Holzel H, Morgan G, Novelli VM. Tuberculosis of the central nervous system in children: a 20-year survey. J Infect. 2000; 41:61-8.

6. Solomon T, Dung NM, Kneen R, Gainsborough M, Vaughn DW, Khanh VT. Japanese encephalitis. J Neurol Neurosurg Psychiatry 2000; 68: 405-15.

7. Solomon T. Flavivirus encephalitis. N Engl J Med 2004; 351 : 370-8.

8. Bohr V, Paulson OB, Rasmussen N. Pneumococcal meningitis: late neurologic sequelae and features of prognostic impact. Arch Neurol. 1984; 41: 1045-9.

9. Baraff LJ, Lee SI, Schriger DL. Outcomes of bacterial meningitis in children: a meta-analysis. Pediatr Infect Dis J 1993; 12: 389-94.

10. Scarborough M, Thwaites GE. The diagnosis and management of acute bacterial meningitis in resource-poor settings. Lancet Neurol. 2008; 7: 637-48.

11. Duke T, Curtis N, Fuller DG. The management of bacterial meningitis in children. Expert Opin Pharmacother. 2003; 4: 1227-40.

12. Wall EC, Cartwright $K$, Scarborough $M$, et al. High mortality amongst adolescents and adults with bacterial meningitis in sub-Saharan Africa: an analysis of 715 cases from Malawi. PLoS One. 2013; 8: e69783.

13. Gessner BD, Mueller JE, Yaro S. African meningitis belt pneumococcal disease epidemiology indicates a need for an effective serotype 1 containing vaccine, including for older children and adults. BMC Infect Dis. 2010; 10: 22.

14. Aronin SI, Peduzzi P, Quagliarello VJ. Community-acquired bacterial meningitis: risk stratification for adverse clinical outcome and effect of antibiotic timing. Ann Intern Med 1998; 129: 862-69.

15. Proulx N, Frechette D, Toye B, Chan J, Kravcik S. Delays in the administration of antibiotics are associated with mortality from adult acute bacterial meningitis. QJM 2005;98:291-98.

16. Miner JR, Heegaard W, Mapes A, Biros M. Presentation, time to antibiotics, and mortality of patients with bacterial meningitis at an urban county medical center. J Emerg Med 2001; 21: 387-92.

17. Auburtin M, Wolff M, Charpentier J, et al. Detrimental role of delayed antibiotic administration and penicillinnonsusceptible strains in adult intensive care unit patients with pneumococcal meningitis: the PNEUMOREA prospective multicenter study. Crit Care Med. 2006; 34: 2758-65.

18. Fitch MT, van de Beek D. Emergency diagnosis and treatment of adult meningitis. Lancet Infect Dis 2007; 7 : 191-200.

19. Attia J, Hatala R, Cook DJ, Wong JG. The rational clinical examination. Does this adult patient have acute meningitis? JAMA 1999; 282: 175-81. 
20. van de Beek D, de Gans J, Spanjaard L, Weisfelt M, Reitsma $\mathrm{JB}$, Vermeulen M. Clinical features and prognostic factors in adults with bacterial meningitis. N Engl J Med. 2004; 351 : 1849-59.

21. Thomas KE, Hasbun R, Jekel J, Quagliarello VJ. The diagnostic accuracy of Kernig's sign, Brudzinski's sign, and nuchal rigidity in adults with suspected meningitis. Clin Infect Dis 2002; 35: 46-52.

22. Bartt R. Acute bacterial and viral meningitis. Continuum (Minneap Minn). 2012; 18: 1255-70.

23. van de Beek D, de Gans J, Tunkel AR, Wijdicks EF. Community-acquired bacterial meningitis in adults. N Engl J Med. 2006; 354: 44-53.

24. Anon. Bacterial meningitis. Continuum. 2002; 8: 7-26.

25. Zunt JR, Baldwin KJ. Chronic and subacute meningitis. Continuum (Minneap Minn). 2012; 18: 1290-318.

26. Sacchi CT, Fukasawa LO, Gonçalves MG, et al; São Paulo RT-PCR Surveillance Project Team. Incorporation of realtime PCR into routine public health surveillance of culture negative bacterial meningitis in São Paulo, Brazil. PLOS One. 2011; 6: e20675.

27. Nguyen $\mathrm{TH}, \mathrm{Tran} \mathrm{TH}$, Thwaites $\mathrm{G}$, et al. Dexamethasone in Vietnamese adolescents and adults with bacterial meningitis. N Engl J Med 2007; 357: 2431-40.

28. Scarborough M, Gordon SB, Whitty CJ, et al. Corticosteroids for bacterial meningitis in adults in sub-Saharan Africa. $N$ Engl J Med 2007; 357: 2441-50.

29. Batuwanthudawe R, Karunarathne K, Dassanayake M, et al. Surveillance of invasive pneumococcal disease in Colombo, Sri Lanka. Clin Infect Dis. 2009; 48(2): S136-40.

30. Batuwanthudawe R, Rajapakse L, Somaratne P, Dassanayake M, Abeysinghe N. Incidence of childhood Haemophilus influenzae type $b$ meningitis in Sri Lanka. Int J Infect Dis. 2010; 14: e372-6.

31. ShahAS, Knoll MD, Sharma PR, et al. Invasive pneumococcal disease in Kanti Children's Hospital, Nepal, as observed by the South Asian Pneumococcal Alliance network. Clin Infect Dis. 2009; 48(2): S123-8.

32. Zaidi AK, Khan H, Lasi R, Mahesar W; Sindh Meningitis Group. Surveillance of pneumococcal meningitis among children in Sindh, southern Pakistan. Clin Infect Dis. 2009; 48 (2): S129-35.

33. Stockdale AJ, Weekes MP, Aliyu SH. An audit of acute bacterial meningitis in a large teaching hospital 2005-10. QJM. 2011; 104: 1055-63.

34. Seneviratne R de S, Navasivayam P, Perera S, Wickremasinghe RS. Microbiology of cerebral abscess at the neurosurgical unit of the National Hospital of Sri Lanka. Ceylon Med J. 2003; 48: 14-16.

35. Peiris JS, Amerasinghe FP, Arunagiri CK, et al. Japanese encephalitis in Sri Lanka: comparison of vector and virus ecology in different agro-climatic areas. Trans $R$ Soc Trop Med Hyg. 1993; 87: 541-8.

36. Peiris JS, Amerasinghe FP, Amerasinghe PH, Ratnayake CB, Karunaratne SH, Tsai TF. Japanese encephalitis in Sri Lanka
- the study of an epidemic: vector incrimination, porcine infection and human disease. Trans R Soc Trop Med Hyg. 1992; 86: 307-13.

37. Gunawardhana SA, Somaratne SC, Fernando MA, Gunaratne PS. Tuberculous meningitis in adults: a prospective study at a tertiary referral centre in Sri Lanka. Ceylon Med J. 2013; 58: 21-5.

38. Ranawaka UK, Rajindrajith EGDS, Perera KV, Dassanayake $\mathrm{KM}$, Premaratne BA, de Silva HJ. Clinical profile and difficulties in diagnosis of central nervous system infections in adult patients in a tertiary care hospital. Ceylon Med $\mathrm{J}$. 2013; 58: 26-8.

39. Mori D, Ranawaka U, Yamada K, et al. Human bocavirus in patients with encephalitis, Sri Lanka, 2009-2010. Emerg Infect Dis. 2013; 19: 1859-62.

40. Phan TG, Mori D, Deng X, Rajindrajith S, Ranawaka U, Fan Ng TF, Bucardo-Rivera F, Orlandi P, Ahmed K, Delwart E. Small circular single stranded DNA viral genomes in unexplained cases of human encephalitis, diarrhea, and in untreated sewage. Virology. 2015; 482: 98-104.

41. Glaser CA, Honarmand S, Anderson LJ, et al. Beyond viruses: clinical profiles and etiologies associated with encephalitis. Clin Infect Dis. 2006; 43: 1565-77.

42. Glaser CA, Gilliam S, Schnurr D, et al. California Encephalitis Project, 1998-2000. In search of encephalitis etiologies: diagnostic challenges in the California Encephalitis Project, 1998-2000. Clin Infect Dis. 2003; 36: 731-42.

43. Michael BD, Sidhu M, Stoeter D, et al. North West Neurological Infections Network. Acute central nervous system infections in adults- a retrospective cohort study in the NHS North West region. QJM. 2010; 103: 749-58.

44. Granerod J, Ambrose HE, Davies NW, et al. UK Health Protection Agency (HPA). Aetiology of Encephalitis Study Group. Causes of encephalitis and differences in their clinical presentations in England: a multicentre, populationbased prospective study. Lancet Infect Dis. 2010; 10: 835-44.

45. Spanos A, Harrell FE Jr, Durack DT. Differential diagnosis of acute meningitis. An analysis of the predictive value of initial observations. JAMA. 1989; 262: 2700-7.

46. Brouwer MC, Tunkel AR, van de Beek D. Epidemiology, diagnosis, and antimicrobial treatment of acute bacterial meningitis. Clin Microbiol Rev. 2010; 23: 467-92.

47. Mitui MT, Tabib SM, Matsumoto T, et al. Detection of human bocavirus in the cerebrospinal fluid of children with encephalitis. Clin Infect Dis. 2012; 54: 964-7.

48. Tan le V, van Doorn HR, Nghia HD, et al. Identification of a new cyclovirus in cerebrospinal fluid of patients with acute central nervous system infections. MBio. 2013; 4: e00 231-13.

49. Smits SL, Zijlstra EE, van Hellemond JJ, et al. Novel cyclovirus in human cerebrospinal fluid, Malawi, 2010-2011. Emerg Infect Dis. 2013; 19: 1511-13.

50. Taylor WR, Nguyen K, Nguyen D, et al. The spectrum of central nervous system infections in an adult referral hospital in Hanoi, Vietnam. PLoS One. 2012; 7: e42099. 
51. Le VT, Phan TQ, Do QH, et al. Viral etiology of encephalitis in children in southern Vietnam: results of a one-year prospective descriptive study. PLoS Negl Trop Dis. 2010; 4: e854

52. Danthanarayana N, Williams DT, Williams SH, Thevanesam V, Speers DJ, Fernando MS. Acute meningoencephalitis associated with echovirus 9 infection in Sri Lanka, 2009. J Med Virol. 2015; 87: 2033-9.

53. Lohitharajah J, Malavige N, Arambepola C, Wanigasinghe J, Gamage R, Gunaratne P, Ratnayake P, Chang T. Viral aetiologies of acute encephalitis in a hospital-based South Asian population. BMC Infect Dis. 2017; 17: 303.

54. Ranawaka UK. The challenge of treating central nervous system infections. Ceylon Med J. 2015; 60: 155-8.

55. Heckenberg SG, de Gans J, Brouwer MC, Weisfelt M, Piet JR, Spanjaard L, van der Ende A, van de Beek D. Clinical features, outcome, and meningococcal genotype in 258 adults with meningococcal meningitis: a prospective cohort study. Medicine (Baltimore). 2008; 87: 185-92.

56. Thigpen MC, Whitney CG, Messonnier NE, et al. Bacterial meningitis in the United States, 1998-2007. N. Eng. J. Med. 2011; 364: 2016-25.

57. Gudina EK, Tesfaye M, Adane A, et al. Challenges of bacterial meningitis case management in Ethiopia. Trop Med Int Health. 2016; 21: 870-8.

58. Mailles A, Stahl JP; Steering Committee and Investigators Group. Infectious encephalitis in France in 2007: a national prospective study. Clin Infect Dis. 2009; 49:1838-47.

59. Davison, KL, Crowcroft NS, Ramsay ME, Brown DW, Andrews NJ. Viral encephalitis in England, 1989-1998: what did we miss? Emerg. Infect. Dis. 2003; 9: 234-240.

60. Koskiniemi M, Rantalaiho T, Piiparinen $\mathrm{H}$, et al. Infections of the central nervous system of suspected viral origin: a collaborative study from Finland. J Neurovirol. 2001; 7: 400-8.

61. Soares CN, Cabral-Castro MJ, Peralta JM, de Freitas MR, Zalis M, Puccioni-Sohler M. Review of the etiologies of viral meningitis and encephalitis in a dengue endemic region. $\mathrm{J}$. Neurol. Sci. 2011; 303: 75-79.

62. Solomon T, Dung NM, Vaughn DW, et al. Neurological manifestations of dengue infection. Lancet 2000; 355: 1053-9.

63. Carod-Artal FJ, Wichmann O, Farrar J, Gascón J. Neurological complications of dengue virus infection. Lancet Neurol. 2013; 12: 906-19.

64. Verma R, Sahu R, Holla V. Neurological manifestations of dengue infection: a review. J Neurol Sci. 2014; 346: 26-34.

65. Anukumar B, Sapkal GN, Tandale BV, Balasubramanian R, Gangale D. West Nile encephalitis outbreak in Kerala, India, 2011. J Clin Virol. 2014; 61: 152-5.

66. Rutvisuttinunt W, Chinnawirotpisan P, Klungthong Cet al.
Evidence of West Nile virus infection in Nepal. BMC Infect Dis. 2014; 14: 606.

67. Lohitharajah J, Malavige GN, Chua AJ, Ng ML, Arambepola $\mathrm{C}$, Chang T. Emergence of human West Nile Virus infection in Sri Lanka. BMC Infect Dis. 2015; 15: 305.

68. Chua KB, Goh KJ, Wong KT, et al. Fatal encephalitis due to Nipah virus among pig-farmers in Malaysia. Lancet 1999; 354: 1257-9.

69. Kulkarni DD, Tosh C, Venkatesh G, Senthil Kumar D. Nipah virus infection: current scenario. Indian J Virol. 2013; 24: 398-408.

70. Homaira N, Rahman M, Hossain MJ, et al. Cluster of Nipah virus infection, Kushtia District, Bangladesh, 2007. PLoS One. 2010; 5: e13570.

71. Homaira N, Rahman M, Hossain MJ, et al. Nipah virus outbreak with person-to-person transmission in a district of Bangladesh, 2007. Epidemiol Infect. 2010; 138: 1630-6.

72. Gudina EK, Tesfaye M, Adane A, Lemma K, Shibiru T, Wieser A, Pfister HW, Klein M. Adjunctive dexamethasone therapy in unconfirmed bacterial meningitis in resource limited settings: is it a risk worth taking? BMC Neurol. 2016; 16: 153.

73. Gable MS, Sheriff H, Dalmau J, Tilley DH, Glaser CA. The frequency of autoimmune $\mathrm{N}$-methyl-d-aspartate receptor encephalitis surpasses that of individual viral etiologies in young individuals enrolled in the California encephalitis project. Clin Infect Dis. 2012; 54: 899-904.

74. Saraya A, Mahavihakanont A, Shuangshoti S, et al. Autoimmune causes of encephalitis syndrome in Thailand: prospective study of 103 patients. BMC Neurol. 2013; 13: 150 .

75. Deresinski S. Encephalitis and Bocavirus? Clin Infect Dis. 2014; 58: iii-iv.

76. Anon. Circular DNA viral genomes in cases of encephalitis. Virology Blog - http://www.virologyhighlights.com/circulardna-viral-genomes-in-cases-of-encephalitis/. Posted on June 30, 2015

77. Yu JM, Chen QQ, Hao YX, Yu T, Zeng SZ, Wu XB, Zhang B, Duan ZJ. Identification of human bocaviruses in the cerebrospinal fluid of children hospitalized with encephalitis in China. J Clin Virol. 2013; 57: 374-7.

78. Zhou C, Zhang S, Gong Q, Hao A. A novel gemycircularvirus in an unexplained case of child encephalitis. Virol J. 2015; 12: 197.

79. Sanya E, Taiwo S, Azeez O, Oluyombo R. Bacteria Meningitis: Problems Of Empirical Treatment In A Teaching Hospital In The Tropics. Internet J Infect Dis. 2006; 6.

80. Molyneux EM, Walsh AL, Forsyth $\mathrm{H}$, et al. Dexamethasone treatment in childhood bacterial meningitis in Malawi: a randomised controlled trial. Lancet 2002; 360: 211-18. 